Рекомендована д. мед. наук, профр. О. М. Олещук

УДК 615.214:541.831.8:004.942:001.53

DOI 10.11603/2312-0967.2018.1.8616

\title{
ПОРІВНЯЛЬНИЙ АНАЛІЗ РЕЗУЛЬТАТІВ IN VIVO СКРИНІНГУ ТА IN SILICO ПРОГНОЗУВАННЯ ПСИХО- ТА НЕЙРОТРОПНИХ ВЛАСТИВОСТЕЙ 3-(N-R,R'- АМІНОМЕТИЛ)-2-МЕТИЛ-1Н-ХІНОЛІН-4-ОНІВ
}

\author{
(с) І. М. Подольський, С. Ю. Штриголь, В. В. Цивунін \\ Національний фрармацевтичний університет, Харків \\ medchem@nuph.edu.ua
}

\begin{abstract}
Мета роботи. Провести аналіз результатів скринінгових in vivo досліджень та ретроспективного in silico прогнозування психо- та нейротропних властивостей 3-(N-R,R'-амінометил)-2-метил-1H-хінолін-4-онів за допомогою програми PASS.

Матеріали і методи. Аналіз результатів попередніх скринінгових in vivo досліджень психо- та нейротропних властивостей 3-(N-R,R'-амінометил)-2-метил-1H-хінолін-4-онів ґрунтувався на опублікованих нами даних. Комп'ютерне прогнозування спектра біологічних властивостей 3-(N-R,R'-амінометил)-2-метил-1H-хінолін-4-онів проведено ретроспективно за допомогою системи PASS Online.

Результати й обговорення. Систематизація та аналіз результатів проведених раніше експериментальних фармакологічних досліджень показали, що більшість 3-(N-R,R'-амінометил)-2-метил-1H-хінолін-4-онів має виразні ноотропні властивості, які у деяких похідних поєднуються 3 високою антидепресивною активністю, протитривожним ефектом, седативними або, навпаки, стимулювальними властивостями. Аналіз результатів для окремих підгруп 3-(N-R,R'-амінометил)-2-метил-1H-хінолін-4-онів дозволив виявити певні зв'язки між хімічною будовою та характером біологічної дії сполук.

Результати PASS-прогнозу показали, що найбільш імовірними біологічними есректами 3-(N-R,R'-амінометил)-2метил-1Н-хінолін-4-онів є здатність виступати інгібіторами убіхінол-цитохром с редуктази, глюконат 2-дегідрогенази, пластохінол-пластоціанін редуктази, кінази рецепторів тромбоцитарного фактора росту та енхансерами експресії 3-гідрокси-3-метилглутарил-КоА синтази 2. Показники для ефектів, які хоча б опосередковано можуть впливати на функції ЦНС (активатори потенціалзалежних кальцієвих каналів та інгібітори вивільнення серотоніну), мають значно нижчі значення.

Висновки. За умови використання комп'ютерного прогнозування спектра фрармакологічної активності 3-(N-R,R'амінометил)-2-метил-1Н-хінолін-4-онів за допомогою програми PASS як основного підґрунтя для подальших скринінгових досліджень цей клас сполук було б втрачено як перспективний в аспекті пошуку нових речовин, здатних впливати на функції ЦНС.
\end{abstract}

Ключові слова: 3-(N-R,R'-амінометил)-2-метил-1Н-хінолін-4-они; нейротропна активність; атристамін; комп'ютерне прогнозування; PASS Online.

Вступ. Стрімкий розвиток медичної хімії в аспекті пошуку принципово нових класів біологічно активних сполук створив передумови для переходу від методу спроб і помилок до раціонального дизайну ліків, коли емпіричний синтез з подальшою перевіркою активності поступається місцем спрямованому конструюванню речовин із бажаними біологічними та фрізикохімічними властивостями. Методи in silico вже достатньо тривалий час $€$ потужним інструментом пошуку нових біологічно активних сполук на початкових етапах дослідження [1, 2]. Вони дозволяють значною мірою оптимізувати відбір структур-кандидатів для подальших експериментальних досліджень in vitro та in vivo, скоротити витрати часу та здешевити етап доклінічного вивчення перспективних сполук.
До визнаних програм віртуального скринінгу слід віднести систему PASS Online [3]. Цей програмний продукт заснований на багатовимірному та систематичному аналізі взаємозв'язку «хімічна структура біологічний ефект» у гетерогенній тренувальній вибірці. Вона порівнює структуру молекули з навчальною вибіркою, яка містить понад 250 тисяч сполук, що дозволяє прогнозувати понад 3500 видів біологічної активності [4]. Окрім можливих фрармакологічних еоректів сполуки, система прогнозує також молекулярні механізми дії та такі небажані побічні есректи, як мутагенність, канцерогенність, тератогенність та ембріотоксичність [5]. До того ж, вона оцінює здатність молекули виступати субстратом того чи іншого ізосрерменту системи цитохрому P450, що дозволяє

ISSN 2312-0967. Pharmaceutical review. 2018. № 1 
Фармакологічні дослідження біологічно активних речовин Pharmacological researches of biologically active substances

припустити можливі шляхи біотрансорормації. Спектр біологічної дії для речовини - це перелік видів біологічної активності, для яких значення вірогідності виявлення $(\mathrm{Pa})$ і невиявлення (Pi) незалежні та коливаються від 0 до 1. При цьому, чим більше значення Ра, тим більше шанс підтвердити дану активність в експерименті [6].

Ідея дослідження 3-(N-R,R'-амінометил)-2-метил1Н-хінолін-4-онів як сполук психо- та нейротропної дії виникла на початку 2000-х років, коли методи in silico не були таким звичним і рутинним інструментом первинного вивчення принципово нових сполук, як тепер. Основна гіпотеза ґрунтувалась на тому, що досліджувані речовини за хімічною будовою мають подібний до серотоніну набір структурних детермінант - і серотонін, і 3-(N-R,R'-амінометил)-2-метил-1Hхінолін-4-они містять бензоконденсовану нітрогеновмісну гетероароматичну систему, що пов'язана 3 аміногрупою (центром осно́вності) лінкером завдовжки 1-2 метиленові групи (рис. 1).

Саме керуючись цим припущенням 3-(N-R, $R^{\prime}$ амінометил)-2-метил-1Н-хінолін-4-они були піддані фрармакологічному скринінгу з використанням стандартних психофрармакологічних тестів, результати яких цілком підтвердили психо- та нейротропний профріль зазначеного класу сполук $[7,8]$.

Мета роботи - проведення аналізу результатів скринінгових in vivo досліджень та ретроспективного in silico прогнозування психо- та нейротропних властивостей 3-(N-R,R'-амінометил)-2-метил-1H-хінолін4-онів за допомогою програми PASS.

Матеріали і методи. Об'єкти дослідження (16 похідних 3-(N-R,R'-амінометил)-2-метил-1H-хінолін-4онів) синтезовано на кафредрі медичної хімії Національного фрармацевтичного університету шляхом амінометилювання відповідних 2-метил-1Н-хінолін4-онів за реакцією Манніха (1a-d) [9] $з$ подальшим переамінуванням анілінами та гетериламінами у випадку арил- та гетериламінометилзаміщених похідних (2a-h, 3a,b) та їх ацилюванням для одержання $\mathrm{N}$-бензоїлпохідних (4a,b). Аналіз результатів попередніх скринінгових in vivo досліджень психо- та нейротропних властивостей 3-(N-R, R'-амінометил)-2метил-1Н-хінолін-4-онів ґрунтувався на опублікованих нами даних $[7,8]$. Фармакологічний скринінг про- водився на білих мишах-самцях у два етапи за однаковими протоколами у дозах 10 мг/кг та 100 мг/кг із використанням тесту відкритого поля, тесту піднесеного хрестоподібного лабіринту, тесту підвішування за хвіст, ротарод-тесту. Антиамнестичні властивості вивчали за допомогою тесту умовного реслексу пасивного уникнення на тлі скополамін-індукованої антероградної амнезії. Комп'ютерне прогнозування спектра біологічних властивостей 3-(N-R, R'амінометил)-2-метил-1Н-хінолін-4-онів було проведене ретроспективно за допомогою онлайн-системи PASS Online (http://www.pharmaexpert.ru/passonline/ index.php).

Результати й обговорення. Результати проведених скринінгових in vivo досліджень психо- та нейротропних властивостей 3-(N-R,R'-амінометил)-2метил-1Н-хінолін-4-онів були систематизовані та представлені у таблиці 1 з напівкількісним вираженням виявлених фрармакологічних ефректів.

Як видно з даних таблиці 1, більшість досліджених сполук має виразні ноотропні властивості, які у деяких похідних поєднуються з високою антидепресивною активністю (2a), протитривожним ефектом (1b, 4a, 4b), седативними (2d, 2e) або, навпаки, стимулювальними властивостями (1d, 2a, 2g, 2h). Аналіз результатів для окремих підгруп 3-(N-R,R'амінометил)-2-метил-1Н-хінолін-4-онів дозволив виявити певні зв'язки між хімічною будовою та характером біологічної дії сполук. Для диметиламінометильних похідних спільною рисою є поєднання антиамнестичних властивостей зі стимулювальним есректом за повної відсутності впливу на депресивність тварин, вплив на тривожність - надчутливий до хімічної модифрікації сполук у межах підкласу. Для 3-ариламінометилзаміщених хінолін-4-онів характерною $є$ висока антиамнестична активність, яка може поєднуватись як зі стимулювальними, так і седативними властивостями, а також антидепресивною дією. N-Бензоїльовані похідні виразні ноотропні властивості поєднують із високою анксіолітичною активністю за відсутності суттєвого впливу на депресивність тварин. Найменш привабливими в аспекті подальшого пошуку нових сполук психо- та нейротропної дії в межах підкласу виглядають 3-гетериламінозаміщені похідні.<smiles>[R]N([R])C[C@H]1C(=O)c2ccccc2NC1C</smiles><smiles>NCCc1c[nH]c2ccc(O)cc12</smiles>

3-(N-R,R'-амінометил)-2-метил-1H-хінолін-4-они серотонін

Рис. 1. Хімічна будова 3-(N-R,R'-амінометил)-2-метил-1H-хінолін-4-онів і серотоніну.

ISSN 2312-0967. Фармацевтичний часопис. 2018. № 1 
Фармакологічні дослідження біологічно активних речовин Pharmacological researches of biologically active substances

Таблиця 1. Психо- та нейротропні ефекти 3-(N-R,R'-амінометил)-2-метил-1Н-хінолін-4-онів in vivo<smiles>[R3][R]([H])([H])Cc1c(C)[nH]c2ccccc2c1=O</smiles>

\begin{tabular}{|c|c|c|c|c|c|c|c|}
\hline \multirow[b]{2}{*}{ Шифрр } & \multirow[b]{2}{*}{$\mathrm{R}_{1}$} & \multirow[b]{2}{*}{$\mathrm{R}_{2}$} & \multirow[b]{2}{*}{$\mathrm{R}_{3}$} & \multicolumn{4}{|c|}{ Eqрект in vivo } \\
\hline & & & & $\begin{array}{l}\text { стимулю- } \\
\text { вальний }\end{array}$ & $\begin{array}{c}\text { антидепре- } \\
\text { сивний }\end{array}$ & $\begin{array}{c}\text { проти- } \\
\text { тривожний }\end{array}$ & $\begin{array}{c}\text { ноотропний/ } \\
\text { антиамнестичний }\end{array}$ \\
\hline \multicolumn{8}{|c|}{ Диметиламінометильні похідні } \\
\hline $1 a$ & $\mathrm{CH}_{3}$ & $\mathrm{CH}_{3}$ & $\mathrm{H}$ & + & 0 & 0 & +++ \\
\hline $1 \mathrm{~b}$ & $\mathrm{CH}_{3}$ & $\mathrm{CH}_{3}$ & $8-\mathrm{CH}_{3}$ & + & 0 & +++ & +++ \\
\hline $1 \mathrm{c}$ & $\mathrm{CH}_{3}$ & $\mathrm{CH}_{3}$ & $6-\mathrm{OCH}_{3}$ & + & 0 & --- & +++ \\
\hline $1 d$ & $\mathrm{CH}_{3}$ & $\mathrm{CH}_{3}$ & $8-\mathrm{OCH}_{3}$ & ++ & 0 & 0 & + \\
\hline \multicolumn{8}{|c|}{ Ариламінометильні похідні } \\
\hline $2 a$ & & $\mathrm{H}$ & $\mathrm{H}$ & ++ & +++ & - & +++ \\
\hline $2 b$ & & $\mathrm{H}$ & $\mathrm{H}$ & 0 & + & 0 & +++ \\
\hline $2 c$ & & $\mathrm{H}$ & $\mathrm{H}$ & 0 & + & 0 & +++ \\
\hline $2 d$ & & $\mathrm{H}$ & $\mathrm{H}$ & - & 0 & $+1-$ & +++ \\
\hline $2 e$ & & $\mathrm{H}$ & $\mathrm{H}$ & -- & 0 & 0 & +++ \\
\hline $2 f$ & & $\mathrm{H}$ & $\mathrm{H}$ & + & - & - & +++ \\
\hline $2 g$ & & $\mathrm{H}$ & $\mathrm{H}$ & ++ & 0 & + & ++ \\
\hline $2 \mathrm{~h}$ & & $\mathrm{H}$ & $6-\mathrm{OCH}_{3}$ & +++ & $+1-$ & 0 & +++ \\
\hline \multicolumn{8}{|c|}{ Гетериламінометильні похідні } \\
\hline $3 a$ & & $\mathrm{H}$ & $\mathrm{H}$ & + & 0 & 0 & + \\
\hline $3 b$ & & $\mathrm{H}$ & $\mathrm{H}$ & 0 & 0 & 0 & + \\
\hline \multicolumn{8}{|c|}{ N-Бензоїльовані ариламінометильні похідні } \\
\hline $4 a$ & & & $\mathrm{H}$ & $+1-$ & - & +++ & ++ \\
\hline $4 b$ & & & $\mathrm{H}$ & 0 & $+1-$ & +++ & ++ \\
\hline
\end{tabular}

Примітка. + або - - напрямок ефекту; +++, ++, + - виразність ефекту; +/- - дозозалежна інверсія ефекту; 0 - відсутність ефекту.

ISSN 2312-0967. Pharmaceutical review. 2018. № 1 
Фармакологічні дослідження біологічно активних речовин Pharmacological researches of biologically active substances

За результатами проведених досліджень 2-метил3-(френіламінометил)-1Н-хінолін-4-он 2а у дозі 100 мг/кг під лабораторною назвою «Атристамін» поглиблено вивчається як перспективний антидепресант із ноотропними, антигіпоксичними, актопротекторними, церебропротекторними та анальгетичними властивостями [7, 10-13]. У таблиці 2 стисло наведено основні види фрармакологічної активності атристаміну, що їх ілюстровано кількісними результатами відповідних тестів.

3 метою підтвердження серотонінергічної гіпотези щодо механізму біологічної дії атристаміну за допомогою ELISA методів було досліджено його вплив на рівень церебральних моноамінів у головному мозку мишей. Експеримент показав, що достовірне зниження концентрації 5-гідрокситриптаміну (-16,8 \%, $\mathrm{p}<0,05)$ поєднується 3 підвищеним рівнем досраміну (+22,0\%) і адреналіну (+13,0\%) після введення атристаміну у дозі 100 мг/кг [14].

Таким чином, аналіз даних обох скринінгових in vivo досліджень психо- та нейротропних властивостей 3-(N-R,R'-амінометил)-2-метил-1H-хінолін-4-онів і поглибленого вивчення фрармакологічних ефректів атристаміну доводить, що цей клас сполук є перспективним для подальшого пошуку нових об'єктів. Не- однорідність отриманих результатів підкреслює прецизійність механізмів фрармакологічної дії досліджуваних сполук, оскільки мінімальні варіації хімічної структури призводять до значних змін у спектрі нейротропних ефректів.

За наявності конкретних результатів фрармакологічного скринінгу 3-(N-R,R'-амінометил)-2-метил-1Hхінолін-4-онів як сполук з психо- та нейротропними властивостями вважали за доцільне провести ретроспективне комп'ютерне прогнозування спектра біологічної активності за допомогою програмного комплексу PASS Online з метою їх зіставлення.

Основні результати PASS-прогнозу спектра біологічної активності 3-(N-R,R'-амінометил)-2-метил-1Hхінолін-4-онів наведено у таблиці 3, де представлено п'ять найвищих показників, які систематично зустрічаються у сполук даного класу, а також найбільші показники ефектів, що можуть бути асоційовані із впливом на фрункції ЦНС.

Як видно 3 даних таблиці 3, найбільш імовірними біологічними ефектами є здатність виступати інгібіторами убіхінол-цитохром с редуктази, глюконат 2-дегідрогенази, пластохінол-пластоціанін редуктази, кінази рецепторів тромбоцитарного фрактора росту (PDGF) та енхансерами експресії 3-гідрокси-3-

Таблиця 2. Основні результати вивчення фрармакологічних ефректів 2-метил-3-(феніламінометил)-1Н-хінолін-4-ону (атристаміну)

\begin{tabular}{|c|c|c|c|c|}
\hline \multirow{2}{*}{\multicolumn{2}{|c|}{ Тест, показники }} & \multirow{3}{*}{$\begin{array}{l}\text { Інтактний } \\
\text { контроль }\end{array}$} & \multicolumn{2}{|c|}{ Атристамін } \\
\hline & & & \multirow{2}{*}{$\begin{array}{c}10 \mathrm{мг/кг} \\
93,2 \pm 7,3\end{array}$} & \multirow{2}{*}{$\begin{array}{c}100 \mathrm{мг/кг} \\
32,7 \pm 16,3^{*} \\
(-71,0 \%)\end{array}$} \\
\hline $\begin{array}{c}\text { Антидепресивна активність - } \\
\text { тест підвішування за хвіст }\end{array}$ & $\begin{array}{c}\text { Загальний час } \\
\text { іммобільності тварин, с }\end{array}$ & & & \\
\hline $\begin{array}{l}\text { Ноотропні властивості - } \\
\text { тест УРПУ на тлі скополамін- } \\
\text { індукованої амнезії }\end{array}$ & $\begin{array}{c}\text { Антиамнестична } \\
\text { активність, \% }\end{array}$ & - & 91,6 & 84,3 \\
\hline \multirow[t]{6}{*}{ Тест відкритого поля } & $\begin{array}{l}\text { Кількість перетнутих } \\
\text { квадратів }\end{array}$ & $25,7 \pm 5,9$ & $37,4 \pm 9,1$ & $40,3 \pm 7,8$ \\
\hline & $\begin{array}{l}\text { Кількість обстежених } \\
\text { отворів }\end{array}$ & $13,3 \pm 4,0$ & $16,8 \pm 1,2$ & $13,7 \pm 2,1$ \\
\hline & $\begin{array}{l}\text { Кількість вертикальних } \\
\text { стійок }\end{array}$ & $4,3 \pm 0,9$ & $3,2 \pm 1,1$ & $10,7 \pm 1,4^{*}$ \\
\hline & $\begin{array}{c}\text { Кількість фрекальних } \\
\text { болюсів } \\
\end{array}$ & $0,1 \pm 0,1$ & $0,4 \pm 0,2$ & $0,7 \pm 0,5$ \\
\hline & Кількість уринацій & 0 & 0 & 0 \\
\hline & Кількість актів грумінгу & $0,9 \pm 0,3$ & $1,4 \pm 0,4$ & $2,3 \pm 0,6^{*}$ \\
\hline $\begin{array}{c}\text { Антигіпоксична активність - } \\
\text { гостра нормобарична гіпоксія } \\
3 \text { гіперкапнією }\end{array}$ & $\begin{array}{l}\text { Тривалість життя тварин } \\
\text { до агонального вдиху, хв }\end{array}$ & $18,4 \pm 0,5$ & н/д & $\begin{array}{l}20,9 \pm 0,7^{*} \\
(+13,6 \%)\end{array}$ \\
\hline $\begin{array}{c}\text { Актопротекторна активність } \\
\text { - тест плавання } 3 \\
\text { навантаженням }\end{array}$ & Час плавання, с & $4,3 \pm 0,8$ & н/д & $\begin{array}{l}12,8 \pm 4,0^{*} \\
(+298,0 \%)\end{array}$ \\
\hline $\begin{array}{l}\text { Анальгетична дія - тест } \\
\text { теплової імерсії хвоста }\end{array}$ & $\begin{array}{c}\text { Час висмикування хвоста } \\
\text { (90 хв та } 120 \text { хв після } \\
\text { введення), с }\end{array}$ & $\begin{array}{l}1,9 \pm 0,1 \\
2,9 \pm 0,4\end{array}$ & н/д & $\begin{array}{l}3,1 \pm 0,5^{*} \\
5,9 \pm 1,6^{*}\end{array}$ \\
\hline
\end{tabular}

Примітка. * - достовірно з р<0,05 порівняно 3 інтактним контролем (Student's t-test); н/д - не досліджувалось.

ISSN 2312-0967. Фармацевтичний часопис. 2018. № 1 
Фармакологічні дослідження біологічно активних речовин Pharmacological researches of biologically active substances

Таблиця 3. Систематичні есректи 3-(N-R,R'-амінометил)-2-метил-1H-хінолін-4-онів, спрогнозовані за допомогою системи PASS Online

\begin{tabular}{|c|c|c|c|c|c|c|c|}
\hline \multirow{3}{*}{ 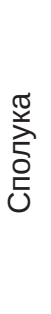 } & \multicolumn{7}{|c|}{ Прогнозована активність/ефект } \\
\hline & \multicolumn{5}{|c|}{ ТОП-5 } & \multicolumn{2}{|c|}{$\begin{array}{l}\text { Есректи, асоційовані з психо- } \\
\text { та нейротропним профрілем дії }\end{array}$} \\
\hline & $\begin{array}{l}\text { Ubiquinol- } \\
\text { cytochrome-c } \\
\text { reductase } \\
\text { inhibitor }\end{array}$ & $\begin{array}{l}\text { Platelet derived } \\
\text { growth factor } \\
\text { receptor kinase } \\
\text { inhibitor }\end{array}$ & $\begin{array}{c}\text { Gluconate } \\
\text { 2-dehydro- } \\
\text { genase } \\
\text { (acceptor) } \\
\text { inhibitor }\end{array}$ & $\begin{array}{l}\text { Plastoquinol- } \\
\text { plastocyanin } \\
\text { reductase } \\
\text { inhibitor }\end{array}$ & $\begin{array}{l}\text { HMGCS2 } \\
\text { expression } \\
\text { enhancer }\end{array}$ & $\begin{array}{c}\text { Calcium } \\
\text { channel } \\
\text { (voltage- } \\
\text { sensitive) } \\
\text { activator }\end{array}$ & $\begin{array}{l}\text { 5-Hydroxytry- } \\
\text { ptamine } \\
\text { release } \\
\text { inhibitor }\end{array}$ \\
\hline $1 \mathbf{a}$ & $\frac{0,775}{0,041}$ & - & $\frac{0,600}{0,122}$ & $\frac{0,632}{0,005}$ & $\frac{0,657}{0,012}$ & $\frac{0,599}{0,024}$ & - \\
\hline 1b & $\frac{0,757}{0,048}$ & - & - & $\frac{0,571}{0,012}$ & $\frac{0,562}{0,021}$ & $\frac{0,615}{0,019}$ & - \\
\hline 1c & $\frac{0,768}{0,044}$ & - & $\frac{0,772}{0,024}$ & $\frac{0,647}{0,005}$ & $\frac{0,573}{0,020}$ & $\frac{0,651}{0,011}$ & - \\
\hline 1d & $\frac{0,742}{0,053}$ & - & $\frac{0,716}{0,048}$ & $\frac{0,601}{0,008}$ & $\frac{0,553}{0,022}$ & $\frac{0,658}{0,010}$ & - \\
\hline $2 \mathbf{a}$ & $\frac{0,786}{0,037}$ & $\frac{0,745}{0,005}$ & $\frac{0,635}{0,098}$ & $\frac{0,674}{0,004}$ & $\frac{0,665}{0,012}$ & $\frac{0,568}{0,037}$ & $\frac{0,533}{0,021}$ \\
\hline 2b & $\frac{0,712}{0,064}$ & $\frac{0,726}{0,005}$ & $\frac{0,541}{0,167}$ & $\frac{0,658}{0,004}$ & $\frac{0,605}{0,017}$ & $\frac{0,607}{0,021}$ & $\frac{0,516}{0,025}$ \\
\hline 2c & $\frac{0,761}{0,046}$ & $\frac{0,736}{0,005}$ & - & $\frac{0,658}{0,004}$ & $\frac{0,605}{0,017}$ & $\frac{0,562}{0,040}$ & $\frac{0,529}{0,022}$ \\
\hline $2 d$ & $\frac{0,760}{0,047}$ & $\frac{0,628}{0,012}$ & $\frac{0,742}{0,035}$ & $\frac{0,684}{0,004}$ & $\frac{0,694}{0,010}$ & $\frac{0,607}{0,021}$ & - \\
\hline $2 e$ & $\frac{0,781}{0,039}$ & $\frac{0,673}{0,008}$ & $\frac{0,771}{0,024}$ & $\frac{0,709}{0,003}$ & $\frac{0,593}{0,018}$ & $\frac{0,641}{0,013}$ & $\frac{0,510}{0,026}$ \\
\hline $2 f$ & $\frac{0,602}{0,107}$ & $\frac{0,677}{0,008}$ & - & $\frac{0,586}{0,010}$ & $\frac{0,570}{0,020}$ & $\frac{0,572}{0,035}$ & - \\
\hline $2 g$ & $\frac{0,670}{0,080}$ & $\frac{0,631}{0,011}$ & - & $\frac{0,541}{0,017}$ & - & $\frac{0,618}{0,018}$ & $\frac{0,525}{0,023}$ \\
\hline $2 \mathrm{~h}$ & $\frac{0,767}{0,044}$ & $\frac{0,673}{0,008}$ & $\frac{0,792}{0,018}$ & $\frac{0,688}{0,004}$ & $\frac{0,576}{0,019}$ & $\frac{0,629}{0,015}$ & $\frac{0,500}{0,029}$ \\
\hline $3 \mathbf{a}$ & - & $\frac{0,707}{0,006}$ & $\frac{0,598}{0,124}$ & - & $\frac{0,640}{0,014}$ & - & - \\
\hline 3b & - & - & - & - & - & - & $\frac{0,547}{0,019}$ \\
\hline $4 a$ & $\frac{0,581}{0,115}$ & $\frac{0,507}{0,029}$ & - & $\frac{0,577}{0,011}$ & $\frac{0,567}{0,020}$ & - & - \\
\hline 4c & $\frac{0,547}{0,130}$ & - & $\frac{0,544}{0,165}$ & - & $\frac{0,613}{0,016}$ & $\frac{0,503}{0,076}$ & - \\
\hline
\end{tabular}

метилглутарил-КоА синтази 2. Показники для ефектів, які хоча б опосередковано можуть впливати на функції ЦНС (активатори потенціалозалежних кальцієвих каналів та інгібітори вивільнення серотоніну), мають значно нижчі значення. Фармакологічна користь від цих ефректів в аспекті пошуку лікарських речовин є дискутабельною.

Слід зауважити, що серед результатів, які не включено до зведеної таблиці, зустрічаються поодинокі ефекти, що належать до психо- та нейротропного профрілю та мають високу вірогідність. Наприклад, для сполуки 1а спрогнозовано антигіпоксичну ( $\mathrm{Pa}=0,688 ; \mathrm{Pi}=0,009)$, антиневротичну ( $\mathrm{Pa}=0,597$; $\mathrm{Pi}=0,072)$ активності та здатність виступати інгібітором зворотного захоплення нейромедіаторів (Pa=0,546; $\mathrm{Pi}=0,045)$. Але внаслідок своєї несистематичності такі ефекти не привертають особливої уваги і сприймаються як спорадичні.

Отже, аналіз отриманих результатів виявив, що серед найвищих показників 3-(N-R, R'-амінометил)-2-

ISSN 2312-0967. Pharmaceutical review. 2018. № 1 
Фармакологічні дослідження біологічно активних речовин Pharmacological researches of biologically active substances

метил-1Н-хінолін-4-онів майже не зустрічаються ефекти, що можуть бути віднесені до психо- та нейротропного профрілю біологічної активності. Оскільки прийняття рішення відносно спрямованості експериментального скринінгового вивчення нових синтезованих речовин є відповідальним етапом, результати будь-якого in silico дослідження мають бути переконливими. У випадку комп'ютерного прогнозування 3-(N-R, R'амінометил)-2-метил-1Н-хінолін-4-онів одержані дані категорично не дозволяють припустити у досліджених сполук психо- та нейротропні види активності та спрямувати пошук у зазначеному напрямку.

Висновки. 1. Проведено систематичний аналіз результатів двох скринінгових in vivo досліджень 3-(N-R, R'-амінометил)-2-метил-1H-хінолін-4-онів та виявлено певні зв'язки між хімічною структурою та фрармакологічними ефектами.

2. За допомогою системи PASS Online ретроспективно здійснено прогнозування спектра біологічної активності зазначеного класу сполук.
3. Проведено порівняльний аналіз результатів скринінгових in vivo досліджень та ретроспективного in silico прогнозування психо- та нейротропних властивостей 3-(N-R,R'-амінометил)-2-метил-1H-хінолін4-онів з метою їх зіставлення.

4. Показано, що серед найвищих показників прогнозованих видів активності майже не зустрічаються ефекти, що можуть бути асоційовані 3 психо- та нейротропним профрілем активності та здатні спрямувати експериментальні дослідження у цьому напрямку.

5. Доведено, що за умови використання комп'ютерного прогнозування спектра фрармакологічної активності 3-(N-R,R'-амінометил)-2-метил-1Hхінолін-4-онів за допомогою програми PASS як основного підґрунтя для подальших скринінгових досліджень цей клас сполук було б втрачено як перспективний в аспекті пошуку нових речовин, здатних впливати на фрункції ЦНС.

\title{
СРАВНИТЕЛЬНЫЙ АНАЛИЗ РЕЗУЛЬТАТОВ IN VIVO СКРИНИНГА И IN SILICO ПРОГНОЗИРОВАНИЯ ПСИХО- И НЕЙРОТРОПНЫХ СВОЙСТВ 3-(N-R,R'-АМИНОМЕТИЛ)-2-МЕТИЛ-1Н-ХИНОЛИН-4-ОНОВ
}

\author{
И. Н. Подольский, С. Ю. Штрыголь, В. В. Цывунин \\ Национальный фрармацевтический университет, Харьков \\ medchem@nuph.edu.ua
}

Цель работы. Провести анализ результатов скрининговых in vivo исследований и ретроспективного in silico прогнозирования психо- и нейротропных свойств 3-(N-R,R'-аминометил)-2-метил-1Н-хинолин-4-онов при помощи программы PASS.

Материалы и методы. Анализ результатов предыдущих скрининговых in vivo исследований психо- и нейротропных свойств 3-(N-R,R'-аминометил)-2-метил-1H-хинолин-4-онов основывался на опубликованных нами данных. Компьютерное прогнозирование спектра биологических свойств 3-(N-R,R'-аминометил)-2-метил-1Н-хинолин-4онов было проведено ретроспективно при помощи системы PASS Online.

Результаты и обсуждение. Систематизация и анализ результатов проведенных ранее экспериментальных фрармакологических исследований показали, что подавляющее большинство 3-(N-R, R'-аминометил)-2-метил-1Hхинолин-4-онов имеют выраженные ноотропные свойства, которые у некоторых производных сочетаются с высокой антидепрессивной активностью, противотревожным эфрфектом, седативными или, наоборот, стимулирующими свойствами. Анализ результатов для отдельных подгрупп 3-(N-R,R'-аминометил)-2-метил-1H-хинолин-4-онов позволил выявить определенные связи между химическим строением и характером биологического действия веществ.

Результаты PASS-прогноза показали, что наиболее вероятными биологическими эфрфектами 3-(N-R, R'-аминометил)2-метил-1Н-хинолин-4-онов являются способность выступать ингибиторами убихинол-цитохром с редуктазы, глюконат 2-дегидрогеназы, пластохинол-пластоцианин редуктазы, киназы рецепторов тромбоцитарного фрактора роста и энхансерами экспрессии 3-гидрокси-3-метилглутарил-КоА синтазы 2. Показатели для эфрфектов, которые хотя бы опосредованно могут влиять на фрункции ЦНС (активаторы потенциалзависимых кальциевых каналов и ингибиторы высвобождения серотонина), имеют значительно более низкие значения.

Выводы. При условии использования компьютерного прогнозирования спектра фрармакологической активности 3-(N-R,R'-аминометил)-2-метил-1Н-хинолин-4-онов при помощи программы PASS в качестве предопределяющего основания для дальнейших скрининговых исследований этот класс веществ был бы потерян как перспективный в аспекте поиска новых веществ, способных влиять на функции ЦНС.

Ключевые слова: 3-(N-R,R'-аминометил)-2-метил-1Н-хинолин-4-оны; нейротропная активность; атристамин; компьютерное прогнозирование; PASS Online.

ISSN 2312-0967. Фармацевтичний часопис. 2018. № 1 
Фармакологічні дослідження біологічно активних речовин Pharmacological researches of biologically active substances

\title{
COMPARATIVE ANALYSIS OF IN VIVO SCREENING AND IN SILICO PREDICTION RESULTS OF PSYCHO- AND NEUROTROPIC PROPERTIES OF 3-(N-R,R'-AMINOMETHYL)-2-METHYL-1H-QUINOLIN- 4-ONES
}

\author{
I. M. Podolsky, S. Yu. Shtrygol', V. V. Tsyvunin \\ National University of Pharmacy, Kharkiv \\ medchem@nuph.edu.ua
}

The aim of the work. To analyze and compare the results of screening in vivo studies and retrospective in silico prediction of the psycho- and neurotropic properties of 3-(N-R,R'-aminomethyl)-2-methyl-1H-quinoline-4-ones.

Materials and Methods. Analysis of the results of previous screening in vivo studies of the psycho- and neurotropic properties of 3-(N-R,R'-aminomethyl)-2-methyl-1H-quinoline-4-ones was based on the data published previously. Computer-aided prediction of the spectrum of the biological properties of 3-(N-R,R'-aminomethyl)-2-methyl- $1 \mathrm{H}-$ quinoline4-ones was carried out retrospectively using the PASS Online system.

Results and Discussion. Systematization and analysis of the results of previous experimental pharmacological studies showed that the most of 3-(N-R,R'-aminomethyl)-2-methyl-1H-quinoline-4-ones presented have pronounced nootropic properties, which for some derivatives are combined with high antidepressant activity, anti-anxiety effect, sedative or, conversely, stimulating properties. Analysis of the results for subgroups of 3-(N-R,R'-aminomethyl)-2-methyl-1H-quinolin4-ones allowed us to reveal certain relationships between the chemical structure and the profile of the biological action. The results of the PASS-prediction showed that the most probable biological effects of 3-(N-R,R'-aminomethyl)-2-methyl$1 \mathrm{H}$-quinoline-4-ones are the ability to act as inhibitors of ubiquinol-cytochrome c reductase, gluconate 2-dehydrogenase, plastoquinol-plastocyanin reductase, platelet-derived growth factor receptor kinase and 3-hydroxy-3-methylglutaryl-CoA synthase 2 expression enhancers. Parameters for effects that may even indirectly affect the functions of the CNS (calcium channel (voltage-sensitive) activator and 5-hydroxytryptamine release inhibitor) have significantly lower values.

Conclusions. It was justified, that using the computer-aided prediction of the pharmacological activity spectrum of 3-(N-R,R'-aminomethyl)-2-methyl-1H-quinoline-4-ones applying the PASS program as the fundamental basis for further screening studies this class of compounds would have been lost as a promising in the search for new substances that can influence the functions of the central nervous system.

Key words: 3-(N-R,R'-aminomethyl)-2-methyl-1H-quinoline-4-ones; neurotropic activity; atristamine; computer-aided prediction; PASS Online.

\section{Список літератури}

1. The Handbook of Medicinal Chemistry: Principles and Practice / Eds: A. Davis, S. E. Ward. - 2014: RCS Publishing. $-753 \mathrm{p}$.

2. The Practice of Medicinal Chemistry (4th Edition) / Eds: C.G. Wermuth, D. Aldous, P. Raboisson, D. Rognan. 2015: Elsevier/Academic Press. - 902 p.

3. Чекман I. C. In silico: новий напрям у розробці фрармакологічних та фрармацевтичних властивостей лікарських засобів / І. С. Чекман, Т. Ю. Небесна, П. В. Симонов // Клінічна фрармація. - 2012. - Т. 16, № 2. - C. 4-14.

4. Filz O. A. Design of chemical compounds with desired properties using fragment libraries / O. A. Filz, V. V. Poroikov // Russian Chemical Reviews. - 2012. - Vol. 81, No. 2. - P. 158-174.

5. Mathew B. Synthesis and PASS- assisted in silico approach of some novel 2-substituted benzimidazole bearing a pyrimidine-2,4,6 (trione) system as mucomembranous protector / B. Mathew, J. Suresh, S. Anbazhagan // J. Pharm. Bioallied Sci. - 2013. - No. 5. - P. 39-43.

6. PASS: prediction of activity spectra for biologically active substances / A. Lagunin, A. Stepanchikova, D. Filimonov [et al.] // Bioinformatics. - 2000. - Vol. 16, No. 8. - P. 747-748. 7. Скринінгові дослідження 3-амінометил-2-

метилхінолін-4-онів як потенційних психотропних засобів / С. Ю. Штриголь, В. О. Зубков, І. С. Гриценко [та iн.] // Клінічна фрармація. - 2010. - Т. 14, № 1. - С. 35-38. 8. Podolsky I. M. The psycho- and neurotropic profiling of novel 3-(N-R,R'-aminomethyl)-2-methyl-1H-quinolin-4ones in vivo / I. M. Podolsky, S. Yu. Shtrygol, V. O. Zubkov // Saudi Pharmaceutical Journal. - 2018. - Vol. 26, No. 1. - P. 107-114.

9. 3-Диметиламинометил-2-метил-1Н-хинолин4-он - эфрфективный реагент в синтезе 3-аминометилзамещенных хинолонов / В. А. Зубков, И. С. Гриценко, С. Г. Таран [та ін.] // Журнал органічної та фрармацевтичної хімії. - 2005. - Т. 3, № 2 (10). - С 23-27. 10. 2-Метил-3-срениламинометилхинолин 4-он - потенциальный антидепрессант с ноотропными свойствами / С. Ю. Штрыголь, В. А. Зубков, И. Н. Подольский [и др.] // Экспериментальная и клиническая фрармакология. 2012. - Т. 75, № 4. - С. 7-9.

11. Антигіпоксична активність 2-метил-3-среніламінометилхінолін-4-ону - перспективного антидепресанта 3 ноотропними властивостями / І. М. Подольський, С. Ю. Штриголь, В. Ф. Осташко [та ін.] // Український біофрармацевтичний журнал. - 2013. - № 2 (25). - С. 4649 .

ISSN 2312-0967. Pharmaceutical review. 2018. № 1 
Фармакологічні дослідження біологічно активних речовин Pharmacological researches of biologically active substances

12. Podolsky I. M. Neuroprotective activity of 2-methyl3-phenylamino-methylquinolin-4-one in experimental traumatic brain injury in rats / I. M. Podolsky, S. Yu. Shtrygol // Journal of Chemical and Pharmaceutical Research. 2015. - Vol. 7 (4). - P. 518-524.

13. Podolsky I. The analgesic properties of a promising antidepressant - 2-methyl-3-(phenylaminomethyl)-1H-

\section{References}

1. Davis A, Ward SE (eds). The Handbook of Medicinal Chemistry: Principles and Practice. London: RCS Publishing; 2014. Available from: http://dx.doi. org/10.1039/9781782621836.

2. Wermuth CG, Aldous D, Raboisson P, Rognan D (eds). The Practice of Medicinal Chemistry, 4th Edition. San Diego: Elsevier/Academic Press; 2015. Available from: https://doi.org/10.1016/B978-0-12-417205-0.00037-7.

3. Chekman IS, Nebesna TYu, Symonov PV. [In silico: the new field in development of pharmacological and pharmaceutical properties of medicines]. Klinichna farmatsiia. 2012;16(2): 4-14. Ukrainian.

4. Filz OA, Poroikov VV. Design of chemical compounds with desired properties using fragment libraries. Russian Chemical Reviews. 2012;81(2): 158-74. Available from: http://dx.doi.org/10.1070/RC2012v081n02ABEH004222.

5. Mathew B, Suresh J, Anbazhagan S. Synthesis and PASS- assisted in silico approach of some novel 2-substituted benzimidazole bearing a pyrimidine-2,4,6 (trione) system as mucomembranous protector. J. Pharm. Bioallied Sci. 2013;5: 39-43. Available from: http://dx.doi. org/10.4103/0975-7406.106563.

6. Lagunin A, Stepanchikova A, Filimonov D, Poroikov V. PASS: prediction of activity spectra for biologically active substances. Bioinformatics. 2000;16(8): 747-8.

7. Shtryhol' SYu, Zubkov VO, Hrytsenko IS, Podolskyi IM, Shatilov OV. [Screening research of 3-aminomethyl2-methylquinolin-4-ones as potential psychotropic agents] Klinichna farmatsiia. 2010;14(1): 35-8. Ukrainian.

8. Podolskyi IM, Shtryhol' SYu, Zubkov VO. The psycho- quinolin-4-one / I. Podolsky, S. Shtrygol // The Pharma Innovation Journal. - 2017. - Vol. 6, No. 8 (C). - P. 156160.

14. Вплив похідних 3-амінометил-2-метилхінолін-4ону на рівень моноамінів у головному мозку мишей / С. Ю. Штриголь, В. О. Зубков, І. М. Подольський [та ін.] // Вісник фрармації. - 2011. - № 1 (65). - С. 62-65.

and neurotropic profiling of novel 3-(N-R,R'-aminomethyl)2-methyl-1H-quinolin-4-ones in vivo. Saudi Pharmaceutical Journal. 2018;26(1): 107-14. Available from: http://dx.doi. org/10.1016/j.jsps.2017.10.005.

9. Zubkov VA, Gritsenko IS, Taran SG, Podolsky IN, Kamenetska OL. [3-Dimethylaminomethyl-2-methyl-1h-quinolin-4-one as an effective reagent in the 3-aminomethylsubstituted quinolones synthesis]. Zhurnal orhanichnoi ta farmatsevtychnoi khimii. 2005;3(2): 23-7. Russian.

10. Shtrygol' SYu, Zubkov VA, Podolsky IN, Gritsenko IS. [2-Methyl-3-phenylaminomethylquinolin-4-on as potential antidepressant with nootropic properties]. Eksperimentalnaya i Klinicheskaya Farmakologiya. 2012;75(4): 7-9. Russian. 11. Podolsky IM, Shtrygol' SYu, Ostashko VF, Bezditko NV. [The research of antihypoxic activity of 2-methyl-3-phenylaminomethylquinolin-4-one - perspective antidepressant with nootropic properties]. Ukrainskyi biofarmatsevtychnyi zhurnal. 2013;2(25): 46-9. Ukrainian.

12. Podolsky IM, Shtrygol' SYu. Neuroprotective activity of 2-methyl-3-phenylamino-methylquinolin-4-one in experimental traumatic brain injury in rats. Journal of Chemical and Pharmaceutical Research. 2015;7(4): 518-24.

13. Podolsky I, Shtrygol' S. The analgesic properties of a promising antidepressant - 2-methyl-3(phenylaminomethyl)-1H-quinolin-4-one. The Pharma Innovation Journal. 2017;6(8): 156-60.

14. Shtrygol' SYu, Zubkov VO, Podolsky IM, Hrytsenko IS. [The influence of 3-aminomethyl-2-methylquinolin-4-one derivatives on monoamines levels in the brain of mice]. Visnyk farmatsii. 2011;1(65): 62-5. Ukrainian. 